\title{
Peer observation as teaching evaluation approach: An attempt to review the research area
}

\author{
Stanislav Michek ${ }^{1 a}$, Monika Perutková ${ }^{2}$ and Marie Brichová ${ }^{1}$ \\ ${ }^{1}$ Faculty of Education - Department of Social Pedagogy, University Hradec Králové (UHK), \\ Hradecká 1227, Hradec Králové 500 03, Czech Republic \\ ${ }^{2}$ Faculty of Education - Institute of preprimary and primary education, UHK, Czech Republic
}

\begin{abstract}
This review sets out to map research relating to the concept of peer observation when teachers observe lesson of another teacher which is on same level. The review builds on journal papers included in the Web of Science and/or ERIC databases. The study uses documents analysis when the units of analysis are concepts of peer observation, research aims and research methods of studies. The review aims to answer the following questions: What are the objectives of studies focused on peer observation of teacher in the studies? Which methods and approaches do the studies use? What are the results of these studies? The authors conclude the review with a summary of its findings and a discussion. There are a number of research instruments and methods for investigating peer observation by qualitative approach, but the challenge now is to develop ways of quantitative research approach.
\end{abstract}

\section{Submitting the manuscript}

This review sets out to map research relating to the concept of peer observation when teachers observe lesson of another teacher which is on same level. The review is based on the experience with using the Peer Review concept in vocational education and training [23, 6 and 14] i.e. the model of evaluation where some professionals are obliged to evaluate the performances of other professionals from the same branch with respect to criteria and the quality standards of performance expected within the framework of the given profession. Experience with peer evaluation was gathered not only in vocational schools in Czech Republic [15]. Observation was very often part of the peer evaluation, and it helped the reviewers to assess the quality criteria of a given vocational education and training provider, when the team of reviewers gathered information about the school assessed by observation. The research made during years 2010-2011 has shown the need to work with competences teachers need to assess their colleagues from the same school (peer review).

\footnotetext{
${ }^{a}$ Corresponding author: stanislav.michek@uhk.cz
} 
Peer review is in this case specified as mutual observations of teachers (peer observation). Another interesting question is how the peer observation contributes to the professional development of teachers.

The review allows to answer the following questions:

- How peer observation is are researched?

- What are the results of peer observation researches?

When conceptualising peer observation, it is necessary to build on the understanding of observation. The classical author of evaluation Michael Scriven [21] describes observation as: "Using classroom visits by colleagues (or administrators or "experts") to evaluate teaching is not just incorrect, it's a disgrace". And he notes 4 reasons, why he considers observation to be a problematic method:

- the visit itself alters the teaching, so that the visitor is not looking at a representative sample. This defect is exacerbated by preannouncing the visit.

- the number of visits is too small to be an accurate sample from which to generalize, even if it were a random sample.

- the visitors are typically not devoid of independent personal prejudices in favour of or against the teacher ...

- nothing that could be observed in the classroom ... can be used as a basis for an inference to any conclusion about the merit of the teaching.

On the other hand Peterson [16] emphasizes systematic observation as a process in which a classroom observer records the visible performance of a teacher and an expert analyses the record using some conceptual framework. Bailey adds to this [3] the purposeful examination of teaching and/or learning events through the systematic processes of data collection and analysis. Last, but not least, observation can be a research tool, or used for evaluating teachers, students, classroom, school or curriculum, or for training teachers, or for developing successful teaching skills in the form of Professional Development, [17].

The word, „Peer“ originates from Latin „par“, meaning „,equal“, „same“. Czech psychological dictionary [9] describes the term Peer as „coeval“. Great English-Czech dictionary [10] translates Peer in this meaning as "equal, equivalent, person of the same quality“.

The phenomenon of peer observation is thus a process, during which colleague - teacher records the teacher's visible performance during teaching into a observation record sheet and then, during the observation discussion analyses the strengths and opportunities for improving the teaching he or she visited. What are the objectives and how is peer observation examined - these are the questions this review wants to answer.

\section{Methodology}

\subsection{Purpose of the study}

The objective of the study is to offer the reader structured review of the research from last ten years. Elaboration of the review is guided by the following questions:

-What are the objectives of studies focused on peer observation of teacher in the studies?

-Which methods and approaches do the studies use?

-What are the results of these studies? 


\subsection{Review Methods}

When choosing the studies, the procedure was as follows. First search in the ERIC (The Education Resources Information Center), Web of Science database, which contains reliable sources (mostly reviewed) from pedagogical research. Phrases searched for were: "peer/observation", "teacher/s" and "evaluation". Some articles appeared in both databases, but most of them only in one. The following table shows the procedure for acquiring the articles with combination of various keywords. There were 38 studies total (including articles added from the SAGE publishing house database (pool of articles).

Table 1. Evidence of selection studies.

\begin{tabular}{|c|c|}
\hline Key words/criteria & Articles \\
\hline observation teacher & $\begin{array}{c}\text { Web of Science: } 7172 \text {; } \\
\text { ERIC: } 786\end{array}$ \\
\hline evaluation teacher observation & Web of Science: 668 ERIC: 171 \\
\hline observation teacher model & Web of Science: 550 \\
\hline peer observation teacher evaluation & ERIC: 365 \\
\hline Pool of articles & 38 \\
\hline $\begin{array}{l}\text { peer observation, teacher/s, evaluation, empirical } \\
\text { research, level: teacher observe teacher, not review - } \\
\text { meta analyses }\end{array}$ & $7(8)$ \\
\hline
\end{tabular}

The articles fulfilling the following criteria were chosen form the pool of articles: they were a) journal papers published b) in English, that was c) original research (empirical study) during last d) ten years that was e) available as full text. Study was e) explicitly dealing with the concept of peer observation and inspection was made by a colleague at the same level. We tried not to choose studies which g) involved observation from the point of view of superordinates (administration, managers) or inspections of didactic experts, or supervisors in case of teacher candidates in pre-graduate education. But we added one study to the seven (it is noted in the table as eighth study), which used questionnaires to evaluate the opinion of the observed about the observations (i.e. including observations led by superordinates). But this study [11] has unequivocal conclusion that support peer observation as a tool for professional development of teachers and this is why it was added to the review.

Even with the process described above, the review is restricted: a) only a limited number of databases and full texts available were used. B) Another restriction is that the authors of the review are convinced that mutual observations of teachers help the professional development of teachers. This could have led to them unconsciously avoiding studies that don't support this proposition. C) Another restriction is in omitting review studies dealing with peer observation. This could have led to omitting important research conclusions stated in review studies.

\section{Findings}

Based on the set research questions, we pursued the set goals, or research questions, research methods used and findings of the studies. 


\subsection{Objectives \& questions of peer observation studies}

In their research, individual authors focused on these 3 research questions that influenced the choice of research methods:

- What are teacher perceptions of peer observation as a method for improving teaching and learning? [1, 2, 18 and 19]

- What are the effects of peer observation? [5, 18, 20 and 24]

- How well are teachers able to evaluate their own practice? [7]

Regarding the target group, the situation is more varied: two studies focus on teachers at universities [18 and 24]. Rock \& Wilson [20] deal with teachers at Upper-Elementary school. Gitomer et al. (2014) deal with teachers at middle and high schools. Teachers at Middle School are dealt with also by Daniels et al. [5]. Atkinson \& Bolt [2] research observations for teachers in high education.

\subsection{Results - methods and approaches used in studies}

Qualitative methods were mostly chosen for the set research questions - for 6 out of 7 researches. Among the qualitative methods, most frequent was the design of action research (3 research surveys), also case studies (two cases) and empirical research. One case of observation came with quantitative approach. Number of participants was in line with mostly qualitative approach - small numbers of respondents - teachers; from 2 [24] to 37 [1]. The quantitative research survey observed pedagogical activity of 82 teachers.

From the point of view of research design Anast-May et al. [1] used action research. 37 out of 135 teachers participated here during 2009-2010 from 3 elementary schools. $88 \%$ teachers participated on a pre-conference before observation. Then there were 5 observations for each teacher. Each observation took 60 minutes and it was made by assistant directors. $100 \%$ teachers took part in the post-conference - after-observation discussion, analysis of the teaching observed. The teachers than filled-in questionnaire made of open-ended questions that were divided into three strands: conferencing, feedback and process.

Another action research [2] using interpretative paradigm. 5 respondents - teachers in high education participated. 1st semester: observation of teachers were made, followed by focus group sessions of teachers, at the end of semester the teachers filled in a questionnaire consisting of 11 open ended questions. During the 2 nd semester group debriefing sessions were held and later the researchers gained data using individual emails for teachers and managers.

In 3rd action research [20] 6 teachers - females in 2 groups were researched, when the researchers discussed about their teaching with them. Further University faculty member and the curriculum coordinator had intervention - put research articles for deeply understanding of teaching. The group of teachers changed lessons plan at a workshop. Then observation was made and in the end two hours of reflecting and critiquing for each lesson. To describe the findings, qualitative analyses of (a) participant interviews, (b) field notes/observations, (c) report - teacher reflection journals, were used.

In the empirical research [5] they dealt with 2 middle schools discussions based on the question „How do we know that students are cognitively engaged and learning what we are teaching?" The teachers also made peer observation, and took part in a structured interview. Data were then processed using qualitative analyse (27 codes).

Woodman \& Parappilly [24] made a case study - Longitudinal qualitative research for 2 Early Career University lecturers, who taught different subjects, pairing made randomly 
and it was one teacher - male and one teacher - female. They had in 2007 a peer review of teaching based on Flinders framework including observation. They wrote a report from peer review of teaching and described what peer review of teaching process changed it. Then in 2012 the same teachers made peer evaluation after 5 years and after gaining considerable teaching experience using the same process.

Rajaraman [18] published an essay how she herself as a new academic increased her professional skills based on peer observation by 3 colleagues with different background, while she also observed her colleagues.

Gitomer et al. [7] used quantitative research. It was observation, when each classroom of 82 Algebra I teachers in 20 middle and 20 high schools was observed 4-5 times over the school year. Each observation was coded and scored live and by video by 5 observers. Participating teachers also completed a self-report instrument (CLASS-T).

\subsection{Conclusions of studies - implication for practice}

Even though primarily Lam [11] in his questionnaire survey in Hong Kong deals with teachers' approach to observations, we used her information. Questionnaires were sent to all the 427 secondary schools, 818 primary schools, and 87 special schools in Hong Kong (i.e., all secondary, primary, and special schools in Hong Kong were covered). A total of 5755 questionnaires were mailed to schools. The respondents were requested to return the questionnaires using the stamped envelopes provided by the research team. A total of 2413 questionnaires were returned. The conclusion of the questionnaire survey was that: teachers were more likely than principals to perceive that classroom observation was more for appraisal than for staff development. All respondents indicated that they wished for a model of peer observation and coaching.

The researchers came to these conclusions that were matched in their findings:

-Peer observation and analytic reflection can support teachers as they work toward intentionally improving their pedagogical practices [1, 5, 18, 20 and 24]

- Group development process and peer collaboration activity should continue [2 and 20]. A reason for continuation is also the teachers' interest in their professional development and improvement of their pedagogical activities.

Individual researches also contained partial conclusions that couldn't be generalised for peer observation, but up to a point characterise the use of peer observation. These are the following conclusions:

-there are not experience frequent and extended observations, systematic feedback and a structured reflective approach [1],

- peer observation should be voluntary process [2],

-teachers and external observers view most differently observed lessons [7],

- found the reading and sharing of professional literature and the consultations with experts that directly related to the problem of study were very beneficial to the process [20] . 


\section{Discussion and Conclusion}

In the previous text we introduced the objectives, methodology and results of research studies focused on peer observation of teachers. Now we will try to summarize the findings and discuss them in broader context.

An important theme for us is the question: How to assure generalized view of peer observation? from individual research articles. Here we get to the limits of meta-analysis of qualitative research reports. Another question is whether: Experiences are generalized from different levels? Whether the Woodman \& Parappilly [24] findings from university environment, where they made their longitudinal research would be useful when researching teachers in primary education. Because this review is part of a more complex research aimed at finding the approaches of teachers at the providers of initial vocational education and training towards observation, it is important for us to understand, whether: It is possible to share experiences from studies to initial vocational education and training level? Thanks to this review, we will be better able to design our following research activities.

As the studies were dealing with both inexperienced and experienced teachers, we ask the question, whether it is possible to study the development of teachers' skills necessary for peer observation. These skills are for sure connected with the concept of professional vision [8 and13], an ability to notice [13]. it is quite possible that skills necessary for observing peer teachers, for analysing the observed pedagogical activity, providing descriptive feedback and for making the post-observation discussion are getting higher with teachers' experience and experience with peer observation. But how to survey it is a question to discuss.

The presented means that peer observation is part of professional teacher development. But unfortunately it is not common at different levels of education. A challenge for research is the use of quantitative methods for studying the peer observation of teaching.

\section{Acknowledgment}

This paper was supported from the budget of Czech Republic (grant number 2125 „Komparativní studie hodnocení a rozvíjení kvality výuky $\mathrm{v}$ odborných školách prostřednictvím hospitací"[Comparative study of evaluation and development quality of teaching in vocational education and training schools by observation] funded from the specific research of the Pedagogical faculty of the Hradec Králové University in 2015)

\section{References}

1. Anast-May, L., Penick, D., Schroyer, R., Howell, \& Teacher, A., Conferencing and Feedback: Necessary but Missing! International Journal of Educational Leadership Preparation, 6 (2) (2011)

2. Atkinson, D. J., \& Bolt, S., Using teaching observations to reflect upon and improve teaching practice in higher education. Journal of the Scholarship of Teaching and Learning, 10, (3), 1-19 (2010)

3. Bailey, K.M., Observation. In: Carter, R. and Nunan, D. eds. The Cambridge Guide to Teaching English to Speakers of Other Languages (pp. 114-119). Cambridge: Cambridge University Press (2001) 
4. Beacher, L., McCormack, B., \& Kung, S., Supervisor Use of Video as a Tool in Teacher Reflection. The Electronic Journal for English as a Second Language, 18 (3) (2014)

5. Daniels, E., Pirayoff, R., \& Bessant, S., Using Peer Observation and Collaboration to Improve Teaching Practices. Universal Journal of Educational Research, 1(3), 268-274 (2013)

6. Gutknecht-Gmeiner, M., Externe Evaluierung durch Peer Review. Qualitätssicherung und entwicklung in der beruflichen Erstausbildung. Wiesbaden: VS Verlag (2008)

7. Gitomer, D., Bell, C, Qi, Y., Mccaffrey, D., Hamre, B. K., \& Pianta R. C. The Instructional Challenge in Improving Teaching Quality: Lessons from a Classroom Observation Protocol. Teachers College Record, 116 (060304) (2014)

8. Goodwin, C., Professional vision. American Anthropologist, 96(3), 606-633 (1994)

9. Hartl, P., \& Hartlová, H, Psychologický slovník [Psychological Dictionary]. Praha: Portál (2000)

10. Hais, K., \& Hodek, B., Velký anglicko-český slovník [Great English-Czech Dictionary]. Praha: Academia (1992)

11. Lam, S., Educators' opinions on classroom observation as a practice of staff development and appraisal. Teaching and Teacher Education, 17, 161-173 (2001)

12. Lasagabaster, D. \& Sierra, J. M., Classroom observation: desirable conditions established by teachers. European Journal of Teacher Education, 34, (4), 449-463 (2011)

13. Lefstein, A., \& Snell, J., Professional vision and the politics of teacher learning. Teaching and Teacher Education, 27(3), 505-514 (2011)

14. Michek, S., Pol, M., Chvál, M., Peer Review in School Self-evaluation: Cultivating Skills in Data Use. The New Educational Review, 34 (4), 30-40 (2013)

15. Michek, S., Kolegiální evaluace školy [Peer Review of School]. Hradec Králové: Univerzita Hradec Králové (2014)

16. Peterson, K., D., Teacher Evaluation: A Comprehensive Guide to New Directions and Practices. Thousand Oaks: Corwin Press (2000)

17. Reed, A. J. S. \& Bergemann, V. E., A Guide to Observation, Participation and Reflection in the Classroom. (5th ed) New York: McGraw Hill (2005)

18. Rajaraman, E., Peer Observation of Teaching: Reflections of an Early Career Academic. Universal Journal of Educational Research 2(9), 625-631 (2014)

19. Range, B., Duncan, H., \& Hvidston, D., How Faculty Supervise and Mentor Preservice Teachers: Implications for Principal Supervision of Novice Teachers. International Journal of Educational Leadership Preparation, 8 (2), 43-58 (2013)

20. Rock, T.C. \& Wilson, C., Improving Teaching through Lesson Study. Teacher Education Quarterly (Winter 2005), 77-92 (2005)

21. Scriven, M., Summative Teacher Evaluation. In: Millman, J. ed. Handbook of Teaching Evaluation (pp. 244-271). London: Sage (1981)

22. Sherin, M. G., \& van Es., E. A. Learning to notice: Scaffolding new teachers interpretations of classroom interactions. Journal of Technology and Teacher Education, 10(4), 571-596 (2002)

23. Speer, S., Evaluation report of the Leonardo da Vinci Project Peer Review in Initial Vocational Education and Training. Cologne: Institut für Evaluation Dr. Beywl \& Associates GmbH (2007)

24. Woodman R. J., \& Parappilly, M. B. The Effectiveness of Peer Review of Teaching when performed between Early-career Academics. Journal of University Teaching \& Learning (2013) 